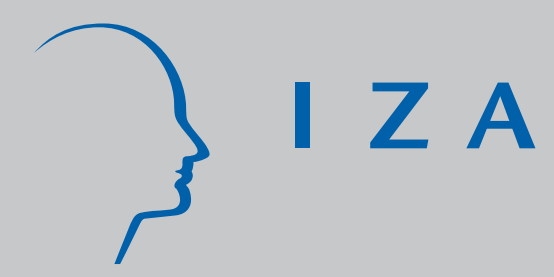

IZA DP No. 3264

Do Immigrants Affect Firm-Specific Wages?

Nikolaj Malchow-Møller

J akob Roland Munch

$\mathrm{J}$ an Rose Skaksen

December 2007 


\title{
Do Immigrants Affect Firm-Specific Wages?
}

\author{
Nikolaj Malchow-Møller \\ CEBR and University of Southern Denmark \\ Jakob Roland Munch \\ University of Copenhagen, CEBR and EPRU \\ Jan Rose Skaksen \\ Copenhagen Business School, CEBR and IZA
}

Discussion Paper No. 3264

December 2007

\author{
IZA \\ P.O. Box 7240 \\ 53072 Bonn \\ Germany \\ Phone: +49-228-3894-0 \\ Fax: +49-228-3894-180 \\ E-mail: iza@iza.org
}

\begin{abstract}
Any opinions expressed here are those of the author(s) and not those of the institute. Research disseminated by IZA may include views on policy, but the institute itself takes no institutional policy positions.

The Institute for the Study of Labor (IZA) in Bonn is a local and virtual international research center and a place of communication between science, politics and business. IZA is an independent nonprofit company supported by Deutsche Post World Net. The center is associated with the University of Bonn and offers a stimulating research environment through its research networks, research support, and visitors and doctoral programs. IZA engages in (i) original and internationally competitive research in all fields of labor economics, (ii) development of policy concepts, and (iii) dissemination of research results and concepts to the interested public.
\end{abstract}

IZA Discussion Papers often represent preliminary work and are circulated to encourage discussion. Citation of such a paper should account for its provisional character. A revised version may be available directly from the author. 


\section{ABSTRACT \\ Do Immigrants Affect Firm-Specific Wages?*}

In this paper, we propose and test a novel effect of immigration on the wages of native workers. Existing studies have focused on the wage effects that result from changes in the aggregate labour supply in a competitive labour market. We argue that if labour markets are not fully competitive, the use of immigrants may also affect wage formation at the most disaggregate level - the workplace. Using linked employer-employee data, we find that an increased use of workers from less developed countries has a significantly negative effect on the wages of native workers at the workplace - also when controlling for potential endogeneity of the immigrant share using both fixed effects and IV. Additional evidence suggests that this effect works at least partly through a general effect on the wage norm in the firm of hiring employees with poor outside options (the immigrants).

JEL Classification: F22, J31

Keywords: immigration, firm-specific wages, outside options

Corresponding author:

Jan Rose Skaksen

Copenhagen Business School

Porcelaenshaven 16A, 1.

DK-2000 Frederiksberg

Denmark

E-mail: jrs.eco@cbs.dk

\footnotetext{
* This paper is part of a joint project between CEBR and the Rockwool Foundation Research Unit. Financial support from the Rockwool Foundation is gratefully acknowledged. The authors wish to thank Anna Piil Damm, Christian Dustmann, Bent Jensen, Peder J. Pedersen, Michael Svarer and Torben Tranæs for many useful comments and suggestions. Vibeke Borchsenius, Jonas Helth Lønborg and David Tønners have provided excellent research assistance. Remaining errors are our own.
} 


\section{Introduction}

Many developed countries have experienced marked increases in immigration in recent decades. As a result, there has been a renewed interest in the economic consequences of immigration, and a number of papers analysing the effects on the wages of native workers have emerged. Although the papers differ in their choice of econometric approach, the underlying idea is the same: Immigration increases the supply of certain types of labour which in turn affects the marginal product of all types of labour and hence the wages of native workers in a competitive labour market. The size and direction of these effects depend both on the realised inflows of immigrants and the assumed or estimated substitution patterns between different types of labour. This is where the disagreement starts. As a consequence, some studies find relatively large negative effects of recent immigrant inflows on the wages of native workers (Borjas, 2003, 2006; Aydemir and Borjas, 2007, and Borjas, Freeman and Katz, 1997), while other studies find much smaller effects (Ottaviano and Peri, 2005, 2006; and Card, 1990, 2001, 2005).

In this paper, we propose and test an additional effect of immigration on the wages of native workers. We argue that immigration may not only affect wage formation through a change in the supply of labour at the aggregate level. If labour markets are not fully competitive, an increased use of immigrants at the firm level may directly influence the wages of native workers employed in the firm. This results in distributional consequences of immigration not captured by the aggregate supply side approach used in the existing literature.

There exists solid empirical evidence that wages are firm specific; see Blanchflower, Oswald and Sanfey (1996), Hildretch and Oswald (1997), and Arai (2003) among others. Local use of immigrants may therefore affect wage formation at the firm level through, e.g., bargaining effects or efficiency wages. Specifically, we shall argue that immigrants employed in a firm often have other outside options (and therefore other wages) than native workers. In particular, many immigrants are likely to have worse outside options due to language and cultural barriers as well as institutional discrimination against 
immigrants. Furthermore, the employment of workers with other/worse outside options may affect not only their own wages, but the wages of all workers in the firm. One possibility is that it signals to other workers that the firm has "access" to relatively cheap labour. This improves the bargaining position of the firm vis-à-vis the workers; see, e.g., Rodrik (1997). Another possibility, which we pursue below, is that the wage norm in the firm changes when workers with different outside options are employed.

To show this, we set up an efficiency wage model where the work effort depends on the extent to which wages are considered to be fair; see Akerlof and Yellen (1990). We then illustrate how an increase in the share of workers with poorer outside options gives rise to a decrease in the wage norm in the firm, which in turn lowers the wages to all workers in the firm. Assuming that outside options are particularly bad for immigrants from less developed countries (LDCs) - and we shall document below that this is the case - the simple theoretical model leads to an immediately testable empirical hypothesis: A higher share of immigrants from less developed countries in the firm (or workplace) employment will reduce the wages of native workers. ${ }^{1}$

This hypothesis is tested using linked employer-employee data for 1993-2004 from a developed country (Denmark) that has experienced a particularly pronounced increase in the employment of immigrants. As we have observations on all individuals in the Danish labour market, we are able to construct very detailed measures of the use of immigrants at the workplace level. Furthermore, as data are register based, measurement problems are negligible. The results are therefore unlikely to suffer from the problem of attenuation bias which has recently been emphasised by Aydemir and Borjas (2005).

\footnotetext{
${ }^{1}$ That outside options are particularly bad for immigrants from less developed countries follows from the fact that most of them are refugees or family reunified who cannot freely move to another country or return to their home country. Furthermore, compared to Danes and other immigrants, they have more restricted access to public benefits, and cultural and language barriers are typically larger than for immigrants from more developed countries. See also Section 3.1 below.
} 
Our OLS estimates do indeed show a significant negative relationship between the share of immigrants from less developed countries in the workplace employment and the wages of native workers. From the OLS estimates we can, however, not conclude whether this represents a causal effect of the immigrants. An alternative explanation may be that certain types of workplaces both attract many immigrants and pay lower wages, or that certain native workers select into workplaces with a high share of immigrants.

While we use fixed effects for each combination of worker and workplace - so-called job-spell fixed effects - to take care of time-invariant omitted variables affecting both the wages of native workers and the share of immigrants, temporary shocks to demand may still lead to reverse causality. A priori, we would expect a positive firm-specific demand shock to increase both the wages of native workers and the immigrant share, as immigrants - due to their higher unemployment rate - are more easily available in the job market; see also Borjas (2001). This in turn creates an upward bias on the OLS and fixed effects estimates of the effect of immigrants on wages.

To deal with this problem, we instrument the share of immigrants in the workplace employment using the historical immigrant share at the workplace (5 years prior to the first year of our sample) interacted with the country level development in the employment of immigrants, which can safely be assumed exogenous to the individual firm. The idea behind this instrument is that workplaces with a high initial share of immigrants are also more likely to receive the largest subsequent inflows of immigrants both due to the presence of immigrant networks and because workplaces that have experience with using immigrants may have lower marginal costs of employing additional immigrants. With fixed effects at the job-spell level, this instrument is by construction valid as long as firm-specific temporary shocks to demand are not too long lasting (more than five years). ${ }^{2}$ Similar types of instruments have also been used by, e.g., Card (2001), Ottaviano and Peri (2005), and Cortes (2006) to instrument the regional shares of immigrants.

\footnotetext{
${ }^{2}$ Note that firm-specific permanent shocks are not a problem here since they will be captured by the jobspell fixed effects.
} 
Our fixed effects and IV estimations confirm that a higher share of immigrants from less developed countries has a negative impact on the wages of native workers. As expected, the IV estimates are also considerably more negative than the other estimates.

To throw some further light on the channel through which LDC immigrants lower the wages of native co-workers, we perform a couple of additional analyses. First, we consider the importance of immigrants from more developed countries. As these immigrants have much better outside options than immigrants from less developed countries, we should expect these to have much less negative effects (if negative at all) on the wages of native workers, provided that our hypothesis about the importance of different outside options is correct. This is exactly what we find.

Second, we run regressions separately for different educational groups of native workers to check whether the effects of immigrants from less developed countries reflect a general effect on the wage norm or a substitution effect at the workplace level in the sense that the native workers most similar to the immigrants see their marginal value and hence their bargaining power decrease. In the latter case, only the wages of less-skilled native workers should be lowered, as these are most similar to the LDC immigrants. However, we find that the use of immigrants from less developed countries affect highskilled and low-skilled native workers almost equally. This strongly suggests that the estimated effect is not simply due to substitution effects at the workplace level, but (at least partly) represents a more general effect on the wage norm in the firm.

The rest of the paper is structured as follows. Data are described in Section 2. In Section 3 , we present our theoretical model and outline the empirical strategy. Section 4 contains the estimation results. Finally, Section 5 concludes. 


\section{Data}

From the Integrated Database of Labour Market Research (IDA), we hold information on all Danish residents in the period 1980-2004. ${ }^{3}$ From IDA, we first extract information about individual characteristics for a $5 \%$ sample of workers for the years 1993-2004. ${ }^{4} \mathrm{We}$ restrict the sample to include only full-time private sector native workers in the age of 1865 years from workplaces with at least 10 employees. Second, this sample is merged with individual information on income from the Income Registers in Statistics Denmark for the same period. Third, as all individuals in IDA are linked to workplaces, the whole population of full-time employees aged 18-65 from IDA is used to construct a number of workplace (and regional) characteristics such as the share of immigrants in the workplace employment. These variables are subsequently merged on to the $5 \%$ sample of workers. After eliminating the observations in the upper and lower 0.5 percentiles of the wage distribution, the final data set for 1993-2004 contains 543,089 observations from 85,892 workers and 42,819 workplaces.

The hourly wage rate is the dependent variable used in the analyses to follow. The wage rate is calculated as total labour income plus mandatory pension payments divided by the total number of hours worked in any given year. The measure for total labour income as such is highly reliable as it comes from the tax authorities.

A number of individual socioeconomic characteristics are used as control variables in the analyses. There is information about age, gender, marital status, the presence of children aged 0-6 years in the household, city size, labour market experience, tenure and education. ${ }^{5}$ Specifically, we work with three levels of education: Basic education, vocational education and higher education. This classification of education levels relies

\footnotetext{
${ }^{3}$ For more details on the IDA data, see Abowd and Kramarz (1999).

${ }^{4}$ Each person present in the period 1993-2004 is given the same probability of being sampled. For the sampled workers, we use observations on all years for which they were employed.

${ }^{5}$ Information about workplace tenure only goes back to 1980 , so an indicator variable for left censored tenure is also included.
} 
on Danish educational codes. Higher education basically corresponds to the two highest categories (5 and 6) in the International Standard Classification of Education (ISCED), i.e., a tertiary education. Vocational education is defined as the final stage of secondary education encompassing programmes that prepare students for direct entry into the labour market. Thus, persons with just high school or equivalent are not included in this category but in the basic education category. Descriptive statistics for the individual characteristics are presented in Table 1.

\section{[Insert Table 1 around here]}

In addition to the variables listed in Table 1, we include individual information on industry of work (19 different industries) and region of residence (51 regions, defined from observed commuting patterns) in the analyses.

With respect to workplace characteristics, we use a variable for the size of the workplace in terms of the number of employees along with a number of variables measuring the composition of the employees. Table 2 summarises the main workplace level variables averaged over workplaces in 2004. Similar variables measuring the composition of employees at the regional level are also constructed and used in the analyses, but not reported in Table 2.

\section{[Insert Table 2 around here]}

Of particular importance is the definition of immigrants used in the paper. Immigrants are defined as individuals born outside Denmark with non-Danish parents, i.e. parents without Danish citizenship or themselves born outside Denmark. If no information is available on the parents, an individual born abroad is also considered an immigrant. As a consequence, in the group of native persons, we include all individuals born in Denmark, irrespectively of the status of the parents, as well as individuals born abroad when at least one parent is Danish. 
In the analyses to follow, we distinguish between three different groups of origin countries for the immigrants: 1) The EU-15 countries plus Norway and Iceland; 2) All remaining developed countries according to the UN definition; and 3) All less developed countries according to the $\mathrm{UN}$ definition. ${ }^{6}$ Note that the origin country of an immigrant is defined from the parents' countries of birth (or citizenship) whenever that information is available. That is, an individual born by Swedish parents in Canada is considered Swedish.

Information on origin countries of the immigrants is used to construct variables measuring the workplace (and regional) shares of the different groups of immigrants among the employees. Summary statistics of these workplace level variables are included in the lower part of Table 2. Note that each immigrant group is only present in about one fourth of the workplaces.

Denmark is an interesting case to study since it is one of the European countries that has experienced the strongest relative increase in the employment of immigrants. Figure 1 shows the development in the importance of each of the three groups of immigrants in total employment in the period 1993-2004. We can see that especially the share of immigrants from less developed countries in total employment has increased dramatically in the period considered. Its share has more than doubled from around 1\% in 1993-94 to well above $2 \%$ ten years later.

[Insert Figure 1 around here]

\section{Theory and Empirical Strategy}

If goods and labour markets are perfectly competitive, workers with identical qualifications will get the same wage, irrespectively of where they work. In that case,

\footnotetext{
${ }^{6}$ The UN definition is available at http://esa.un.org/unpp/definition.html. The last group also includes immigrants with unknown origins, as these are unlikely to belong to the first two groups.
} 
there should be no effects on the wages of native workers from hiring immigrants at the workplace. In contrast, if goods markets are imperfectly competitive and firms earn rents, there may be room for firm-specific wages where firms and workers somehow share the rents. There exists considerable evidence of such rent sharing taking place in practice; see, e.g., Blanchflower, Oswald and Sanfey (1996), Hildretch and Oswald (1997) and Arai (2003). This in turn leaves room for firm and workplace specific characteristics including the use of immigrants - to play a role for individual wages.

If the hiring of immigrants should matter for the wages of native co-workers, immigrants must somehow differ from native workers in economically important ways. Our hypothesis is that immigrants have other outside options. Moreover, immigrants from different parts of the world have different outside options. In Section 3.1, we further argue why we should expect this to be the case and present some evidence to support our claim. Section 3.2 then outlines an efficiency wage model that shows how outside options of individual workers affect wages of all workers in the firm. This model results directly in a testable hypothesis about the link between the share of immigrants in the firm and the wages of native workers. Finally, Section 3.3 presents the empirical strategy used to test this hypothesis.

\subsection{Immigrants and Native Workers}

In this section, we argue that an important difference between native workers and different types of immigrant workers is that they do not have the same options outside the firm.

Above, we distinguished between three groups of immigrants. The first group consists of immigrants from the EU-15 countries, Norway and Iceland. Immigrants from these countries have relatively good options outside their current employment. They can freely move to another EU-country, and they come from countries which are similar to Denmark with respect to culture and institutions. When it comes to immigrants from the Nordic countries, the language barrier is furthermore minimal. Moreover, as (most of) 
these immigrants are EU-citizens, they have the same rights to support from the public sector (including social benefits) as Danish citizens.

The third group is the immigrants from less developed countries (LDC immigrants). We expect these immigrants to have the worst outside options. Most of them have come to Denmark as refugees or as a result of family reunification. Typically, they cannot freely move to another country or return to their home country. Furthermore, they come from countries having a culture and a language which are often very different from the Danish. Finally, they do not have the same rights to support from the public sector as EU citizens.

The second group of immigrants (immigrants from all remaining developed countries) constitutes an intermediate case. Immigrants from these countries have culture and language barriers most similar to those from group 1, and like group 1 immigrants, they are typically free to return to their home country or move on to a third country. However, they do not have the same rights to, e.g., social benefits in Denmark as EU-citizens have.

In sum, we should expect outside options to be particularly bad for immigrants from less developed countries whereas immigrants from EU-15 countries (group 1) are likely to have the best options outside their current employment. For immigrants from groups 1 and 2, outside options may in fact be better than for many Danish employees, as these immigrants also have the option to return to their home country at relatively low costs.

We cannot directly estimate the outside options of the different types of immigrants and native workers as these are determined by their opportunities inside as well as outside Denmark. However, with respect to their opportunities inside Denmark, the average wage and the unemployment rate for workers of their type are at least two rough indications of their options outside their current employment.

The first two columns of Table 3 report the results from two standard Mincer-type regressions where individual wages in 2004 are regressed on the usual explanatory 
variables. ${ }^{7}$ Moreover, we have included dummy variables indicating whether the worker belongs to one of the three immigrant groups. It is the estimated coefficients to these variables that are reported in Table 3.

The results in the third column of Table 3 are from a Probit estimation over the entire workforce where the dependent variable is a dummy for being unemployed in 2004 . Explanatory variables are otherwise as in the wage regressions, except that the industry dummies cannot be included now. The reported numbers are the marginal effects on the unemployment probability of belonging to one of the three groups of immigrants (calculated in the mean of the data).

\section{[Insert Table 3 around here]}

We see that the wages of immigrants from EU-15 countries are almost the same as for native workers. In fact, for full-time employees, the coefficient estimate is slightly positive, although not significant. The wages of LDC immigrants, on the other hand, are between $14.2 \%$ and $15.5 \%$ lower, depending on whether we consider all employees or only full-time employees. As expected, immigrants from other developed countries constitute an intermediate case with wages between $4.6 \%$ and $10.0 \%$ lower than those of native workers.

The picture is the same when it comes to the risk of unemployment, where LDC immigrants have a $10.8 \%$ higher risk of being unemployed. This risk is only $1.3 \%$ and $5.0 \%$ for EU-15 immigrants and immigrants from other developed countries, respectively.

\footnotetext{
${ }^{7}$ The explanatory variables included in the regressions are: age, age squared, sex, and dummy variables for 14 regions, 9 industries, and the three immigrant groups. The regressions are performed on a cross-section from 2004 covering the entire workforce between 18 and 65 years of age. In the wage regressions in columns (1) and (2), we restrict attention to wage workers.
} 
These findings are consistent with results in Husted et al. (2001) who show that both wages and employment probabilities are particularly low for refugee immigrants in Denmark, especially in the first years after their entry.

While the results from Table 3 - and the additional evidence from Husted et al. (2001) do not provide a final proof of outside options being worse for immigrants from less developed countries, they strongly indicate that this is the case. They are also consistent with our conjecture that immigrants from EU-15 are those having the best outside options, whereas group 2 immigrants constitute an intermediate case.

In the analyses to follow, we shall focus on the effects of immigrants from less developed countries (LDC immigrants) as they appear to be the ones with the most pronounced differences relative to the native workers. In Section 4.2, we will, however, return to the importance of the other types of immigrants.

\subsection{An Efficiency Wage Model}

In this section, we show how poor outside options of some employees in a firm (the immigrants) may affect the wages of all workers in the firm. One possibility is that native workers in firms using more immigrant workers may see their bargaining position vis-àvis the firm getting worse. If native workers are considered as being the insiders in the firm with relatively high wages, employment of immigrants with worse outside options may signal to these insiders that the firm has another and cheaper source of labour to draw from. This may in turn weaken the bargaining position of the insiders, i.e., the native workers; see, e.g., Lindbeck and Snower (1986) and Rodrik (1997).

Another possibility is that a trade union in the firm bargains over wages on behalf of all workers in the firm. In case of such collective bargaining, the wage is likely to depend on the average outside option of all the employees; see, e.g., McDonald and Solow (1981). If more immigrant workers imply that the average employee has worse outside options, the wage level in the firm is likely to decrease. 
In the following, we focus on a third possibility, namely that the employment of immigrants affects the wage norm in the firm. Immigrant workers with poor outside options are likely to accept relatively low wages. This is consistent with the empirical evidence above. Therefore, employment of these immigrants may decrease the wage norm in the firm which negatively affects the wages of all other workers in the firm. In the following, we illustrate how this mechanism may work in a simple efficiency wage model building on the fair wage-effort hypothesis present in, e.g., Akerlof and Yellen (1990). ${ }^{8}$

We assume that there are two types of workers in a firm: Native workers and immigrants. The outside option for immigrant workers is $R_{I}$, and for native workers it is $R_{N}$, where $R_{I}$ $<R_{N}{ }^{9}$ The effort of each individual depends on the wage relative to what this individual considers to be a fair wage. In particular, we assume that the effort of individual $i$ is given as:

$$
e_{i}=\left\{\begin{array}{cc}
\left(\frac{W_{i}-W_{i}^{*}}{W_{i}^{*}}\right)^{\beta} & \text { if } \quad W_{i}>W_{i}^{*} \\
0 & \text { otherwise }
\end{array},\right.
$$

where $W_{i}$ is the wage of worker $i$ in the firm, and $W_{i}^{*}$ is the wage which worker $i$ considers to be fair. $\beta$ is the elasticity of the effort with respect to the difference between the actual wage and the fair wage $(0<\beta<1) .{ }^{10}$ The effort function shows that a worker puts more effort into the job if the wage increases relative to what is considered to be the fair wage.

\footnotetext{
${ }^{8}$ A review of the empirical evidence for this model can be found in Howitt (2002).

${ }^{9}$ For the firm, there may be different hiring costs associated with employing the two types of workers, which may explain why the firm employs both types of workers although they end up getting different wages (see below). If the hiring costs of immigrants are higher than those of native workers, the wages of native workers must be higher in an equilibrium where the firm employs both types of labour.

${ }^{10}$ This functional form of the effort function has been used by, e.g., Summers (1988) and Romer (2001).
} 
The firm is assumed to determine the wage rate by minimising the wage per effort unit of the worker, $W_{i} / e_{i}$. This implies that the wage is given as:

$$
W_{i}=\frac{1}{1-\beta} W_{i}^{*}
$$

Next, we assume that the fair wage, $W_{i}^{*}$, depends on the outside option of the worker, $R_{i}$, as well as the wage norm in the firm. In particular, we assume that $W_{i}^{*}$ is given by a weighted average of the two:

$$
W_{i}^{*}=\bar{W}^{\alpha} R_{i}^{1-\alpha}, \quad 0<\alpha<1,
$$

where $\bar{W}$ is the wage norm, which we assume is given as the geometric average of all wages in the firm. ${ }^{11}$ Since there are two types of workers (natives and immigrants), the average wage becomes:

$$
\bar{W}=\left(W_{I}\right)^{S}\left(W_{N}\right)^{1-S},
$$

where $S$ is the immigrant share in the firm, $W_{I}$ is the wage of immigrants (who are all assumed to be identical), and $W_{N}$ is the wage of native workers (also assumed identical). In practice, where workers also differ in terms of observable human capital, we can think of the wages, $W_{I}$ and $W_{N}$, as human-capital adjusted wages.

By using (3) and (4) in (2), we find that:

$$
w_{N}=\frac{c}{1-(1-S) \alpha}+\frac{S \alpha}{1-(1-S) \alpha} w_{I}+\frac{(1-\alpha)}{1-(1-S) \alpha} r_{N}
$$

\footnotetext{
${ }^{11}$ Strictly speaking, it should be the average over all workers in the firm except worker $i$, but if the number of workers is not too small, the two measures will be virtually identical. We proceed as if this is the case.
} 


$$
w_{I}=\frac{c}{1-S \alpha}+\frac{(1-S) \alpha}{1-S \alpha} w_{N}+\frac{1-\alpha}{1-S \alpha} r_{I}
$$

where $w_{N}=\log \left(W_{N}\right), w_{I}=\log \left(W_{I}\right), r_{N}=\log \left(R_{N}\right), r_{I}=\log \left(R_{I}\right)$, and $c=-\log (1-\beta)$. These equations illustrate how the wage of one type of worker spills over to the wage of the other type through the wage norm in the firm. By solving (5) and (6) with respect to $w_{N}$ (and $w_{I}$ ), we find that the wage of native workers in the firm is given by:

$$
w_{N}=\frac{c}{1-\alpha}+r_{N}+\alpha\left(r_{I}-r_{N}\right) S
$$

If the outside options of immigrants and natives are identical, $r_{I}=r_{N}$, it has no implications for the wages of native workers that the firm hires more immigrants. However, if the outside options of the immigrants are worse than the outside options of native workers, $r_{I}<r_{N}$, the wages of native workers in the firm decrease as the share of immigrants goes up. Similarly, if the outside options of immigrants are better than those of native workers, $r_{I}>r_{N}$, the wages of native workers increase if the firm hires more immigrants.

\subsection{Estimation Strategy}

Interpreting $w_{N}$ as the human-capital adjusted wage of native workers, and focusing on immigrants from less developed countries, equation (7) directly gives us an estimable equation for the wages of native workers:

$$
w_{i j t}=a_{0}+a_{1} S_{j t}+a_{2} X_{i j t}+\varepsilon_{i j t},
$$

where $w_{i j t}$ is the $(\log )$ wage of individual $i$ in workplace $j$ in period $t, S_{j t}$ is the share of immigrants from less developed countries in workplace $j$ at time $t$, and $X_{i j t}$ is a vector of time-variant observable individual and workplace characteristics affecting the value of the human-capital of individual $i$ in workplace $j$ at time $t$. Furthermore, $a_{0}=c /(1-\alpha)$ and 
$a_{1}=\alpha\left(r_{I}-r_{N}\right)$. As far as immigrants from less developed countries have outside options which are worse than those of native workers, we expect $a_{1}$ to be negative.

OLS estimation of (8) may be biased for several reasons. First, unobservable workplace characteristics may cause some workplaces to both pay different wages and attract more immigrants. This could be the case for, e.g., foreign-owned firms where it is well established empirically that they pay higher wages; see, e.g., Lipsey (2002). Alternatively, workplaces with unattractive working conditions may be required to pay higher wages (as compensation) and may at the same time attract more immigrants if these are less picky than native workers. Second, unobservable individual characteristics may also be correlated with the immigrant share if certain native workers select the workplaces that hire many (or few) immigrants.

In the estimations to follow, we control for such unobserved workplace and worker characteristics using fixed effects for each combination of worker and workplace (socalled job-spell fixed effects). This results in the following specification of our empirical model:

$$
w_{i j t}=a_{0}+a_{1} S_{j t}+a_{2} X_{i j t}+\varphi_{t}+\theta_{i j}+\varepsilon_{i j t},
$$

where $\theta_{i j}$ is the job-spell fixed effect and $\varphi_{t}$ is a year fixed effect. With fixed effects for each worker-workplace combination, identification is based on changes in the immigrant share at a workplace over time within a job-spell. Here, the relatively long time horizon of our panel (12 years) is very useful.

Still, reverse causality may bias estimates of $a_{1}$ even with fixed effects included as in (9). This could happen if immigrants are attracted to firms that (in some periods) pay higher wages due to unobserved demand shocks. The argument is that immigrants are more likely than native workers to be hired by firms experiencing a positive shock as immigrants are more easily available in the job market and/or have lower mobility costs; 
see Borjas (1999) or Borjas (2001) who argues that immigrants "grease the labour market". This in turn creates an upward bias on the estimate of $a_{1}$ in (9).

To address this problem, we instrument the share of immigrants from less developed countries in workplace $j$ in period $t, S_{j t}$. As instrument, we use the share of LDC immigrants in workplace $j$ in 1987 (five years prior to the first year of our sample) interacted with the country level increase between 1987 and $t$ in the employment of LDC immigrants:

$$
S_{j, 1987} \cdot\left(\frac{\bar{S}_{t}}{\bar{S}_{1987}}\right)
$$

where $\bar{S}_{t}$ and $\bar{S}_{1987}$ are the shares of immigrants from less developed countries in overall employment in year $t$ and 1987, respectively. ${ }^{12}$ Thus, we are basically using the 1987 distribution of immigrants across workplaces to allocate the subsequent increases in immigrant employment at the country level. The idea behind this instrument is that immigrants are likely to obtain employment in workplaces which already employ immigrants. First, because these workplaces have overcome the barriers associated with employing immigrants: They have changed their working language and have made special allowances for cultural and religious diversities, etc. Thus, workplaces that have experience with using immigrants are likely to have lower marginal costs of employing additional immigrants. Second, because of network effects among the immigrants. Networks have previously been shown to be important for the location choices of immigrants as they facilitate assimilation and the job search process; see, e.g., Munshi (2003). It seems reasonable that such networks should also matter for job decisions.

As the country-level development in immigrant employment can safely be assumed exogenous at the workplace level, our instrument is valid by construction as long as the

\footnotetext{
${ }^{12}$ Workplaces that did not exist in 1987 are imputed a value of zero for $S_{j, 1987}$. In Section 4, we also present estimation results which rely on 1990 and 1992 shares instead. This minimises the problem with nonexisting workplaces, but increases the risk of long-lasting temporary shocks biasing the estimates.
} 
unobserved factors determining the historical immigrant shares do not affect subsequent wages. As job-spell fixed effects are included in the IV regressions, this is only a problem if a pre-sample temporary shock to wages (prices) affects both the immigrant share in 1987 and wages in part of the sample period. I.e. the shock should last more than five years. If the shock lasts the entire sample period, however, it will be captured by the fixed effects. Note also that similar types of instruments have previously been used by, e.g., Card (2001), Ottaviano and Peri (2005), and Cortes (2006) to instrument the regional shares of immigrants.

\section{Empirical Results}

This section presents the results of the estimations. Section 4.1 contains the results from estimating the specification in (9), whereas we devote Section 4.2 to further exploration of the underlying mechanisms.

\subsection{Basic Specification}

Table 4 contains the results of estimating three variants of the basic model in (9): A simple pooled OLS estimation, a regression with job-spell fixed effects, and a 2SLS regression with job-spell fixed effects. ${ }^{13}$

Individual control variables included in the regressions are: Dummy variables for six different age groups and three education levels, dummy variables for being married and for children aged 0-6 years in the household, experience, experience squared, tenure, tenure squared, and dummy variables for city size. A number of variables to control for workplace characteristics are also included: The number of employees, the share of employees in different educational groups, the share of employees above 40 years, and

\footnotetext{
${ }^{13}$ The IV estimation is implemented as a two-stage least squares (2SLS) since this may generate more efficient estimates. It should be noted that our potentially endogenous regressor, $S_{j t}$, takes on values in the interval $[0,1]$, so in principle the first stage equation should be a non-linear Tobit. However, Angrist and Krueger (2001) argue that 2SLS is a robust estimation method and that consistency of the second-stage estimates does not depend on getting the first-stage functional form right.
} 
the share of female employees as well as twenty industry dummies. Finally, regional specific time trends and unemployment rates as well as the regional shares of women, older workers and different educational groups in employment are included to control for aggregate supply side effects. To further control for aggregate supply effects of immigration, we also include the shares of the three different groups of immigrants in the regional employment among the regressors. ${ }^{14}$

In the OLS estimation in column (1), we find a significantly negative effect of the LDC immigrant share on the wages of native workers. ${ }^{15}$ The point estimate of $a_{1}$ is -0.25 . This estimate becomes numerically smaller but remains significantly negative in the fixed effects regression in column (2). More specifically, an increase in the share of immigrants from less developed countries of 1 percentage point is found to reduce earnings of native co-workers by approximately $0.14 \%$ when job-spell fixed effects are applied.

\section{[Insert Table 4 around here]}

As argued above, OLS and fixed effects estimates are likely to be biased upwards due to the presence of firm-specific temporary shocks increasing wages and attracting more immigrants. To address this problem, we apply the IV strategy described in the previous section.

The first stage results (available upon request) show that our suggested instrument is highly relevant. The coefficient estimate to the (demeaned) instrument is significantly positive indicating that a higher initial share of immigrants is indeed associated with a

\footnotetext{
${ }^{14}$ An alternative way of controlling for aggregate supply side effects of immigration would be to include the immigrant supply shock within individual $i$ 's own skill-group, as in Borjas (2003). However, as both education and experience are poorly observed for immigrants, we stick to the former approach.

${ }^{15}$ In the OLS regression, standard errors are clustered at the workplace level which implies robust standard errors. In the fixed effects regressions, robust standard errors are used, as the job-spell fixed effects take care of clustering at the workplace and worker level; see Wooldridge (2002).
} 
higher subsequent intake. Furthermore, the first stage F-statistic (reported in column (3) of Table 4) is 62.32, which is well above the critical value of 10 suggested by Staiger and Stock (1997) and Stock and Yogo (2002) to avoid problems with weak instruments that can seriously bias the IV estimates; see also Bound, et al. (1995) and Stock et al. (2002).

The third column in Table 4 contains the relevant parameter estimates from the second stage wage regression. The results from this column confirm that immigrants from less developed countries have a negative effect on the wages of native workers. As expected, the IV estimate is also considerably more negative than the OLS and the fixed effects estimates in columns (1) and (2), although with a somewhat higher standard error as well. An increase in the share of immigrants from less developed countries of 1 percentage point is now found to reduce earnings of native workers by approximately $2.2 \%$, where the $95 \%$ confidence interval ranges from $-1.35 \%$ to $-3.10 \%$.

As a check on the robustness of the IV results, we ran the IV regressions using the 1990shares and 1992-shares of LDC immigrants at the workplace as alternative instruments (both interacted with the country-level development in the employment of LDC immigrants); see columns (4) and (5) in Table 4. Results are very similar with estimated values of $a_{1}$ equal to -1.89 when using the 1992-share and -2.02 when using the 1990share. The values of the first stage F-statistics are, however, somewhat smaller in these cases, indicating that the 1987-share is the strongest instrument.

Finally, we also ran the regression using all three instruments in the first stage regression. This produced a second stage estimate of $a_{1}$ of -2.15 ; see column (6). Furthermore, testing for exogeneity using the Hansen J-statistic in the specification where all three instruments are used, we were not able to reject the null hypothesis that the instruments were exogenous (the p-value was 0.843 ).

\subsection{How do Immigrants Lower Wages?}

The results in Table 4 are strongly supportive of a negative causal impact of immigrant workers from less developed countries on the wages of native co-workers. We have 
hypothesised that this effect arises due to a general effect on the wage norm in the firm when workers with worse outside options are hired (the LDC immigrants). However, we also mentioned in Section 3.2 that there could be several alternative - although related channels through which such a firm-specific effect of the use of immigrants could arise. In this section, we try to shed some further light on the importance of these different channels.

First, in Table 5, we include the shares of immigrants from the two other groups of origin countries: The EU-15 countries (incl. Norway and Iceland) and the other developed countries, respectively. If the effects of immigrants work through their outside options, the effects of a higher share of these other immigrants should be less negative (or even positive) - especially when it comes to the immigrants from the other EU-15 countries. In Table 5, we therefore present results similar to those of Table 4, but with all three immigrant shares included. For the IV regressions, we construct instruments for the additional immigrant shares in exactly the same way as we did for the LDC immigrant share by using the share in a pre-sample year $(1987,1990$ or 1992) interacted with the subsequent country-level increases.

\section{[Insert Table 5 around here]}

We see from Table 5 that the estimates of the coefficients to the two additional immigrant groups are indeed significantly positive in the OLS and FE regressions in columns (1) and (2). They are also positive but, in general, insignificant in the IV regressions in columns (3)-(5), although basing the instruments on the 1990-shares causes the coefficient estimate for EU-15 immigrants to become significantly positive at the 5\% level. In any case, these results are fully in accordance with an effect of immigrants working through their outside options.

Second, we test whether the negative effect of LDC immigrants apply equally to different groups of native workers. If immigrants affect the general wage norm in the firm, we should expect all workers to be affected by an increase in the use of LDC immigrants. If, 
on the other hand, the negative estimate reflects substitution effects within the workplace that lower the marginal product and hence the bargaining power of similar native workers - or it only affects the wage norm for similar workers - then we should expect the effect to be limited to a smaller group of the employees. In particular, we would expect a considerably smaller negative or even a positive effect for high-skilled native workers. The reason is that LDC immigrants are to a very large extent low-skilled workers and/or work in low-skilled jobs. ${ }^{16}$ Hence, firm-level substitution effects should mainly be of relevance to the least educated native workers, whereas higher educated native workers may in fact experience a complementarity effect. These effects can be seen as local versions of the aggregate supply effects of immigration studied in the existing literature; see, e.g., Borjas (2003) and Ottaviano and Peri (2006).

To investigate this issue, we ran the regressions in (9) separately for different educational groups of natives. The results of these estimations are presented in Table 6. The OLS and FE estimates of $a_{1}$ are very similar across the different educational groups. In fact, the most negative OLS estimate is found for those with further education. This strongly suggests that the effect of hiring LDC immigrants is not restricted to similar native workers. Although, the IV estimates in columns (3), (6) and (9) indicate that the effect is most negative for unskilled native workers, the effect for native workers with a further education, column (9), is also strongly negative, and the $95 \%$ confidence intervals for the two parameter estimates overlap quite a bit. The IV estimate for workers with a vocational education is not significantly different from zero, but the instrument is also weakest in this case (the first-stage F-statistic is 14.4).

\section{[Insert Table 6 around here]}

Thus, it seems as if the effects of hiring immigrants from less developed countries are not restricted to the native workers most similar to the immigrants. This in turn suggests that something more than a local substitution effect is at work.

\footnotetext{
${ }^{16}$ In $2004,64 \%$ of the LDC immigrants had basic or unreported education compared to $35 \%$ for native workers.
} 


\section{Conclusion}

In this paper, we have proposed and tested an additional effect of immigration on the wages of native workers. Using detailed employer-employee data from Denmark for the period 1993-2004, we have shown that an increase in the share of immigrants from less developed countries in the workplace employment lowers wages for native co-workers.

We have argued that in a labour market that is not perfectly competitive, such an effect may arise as workers and firms share firm-specific rents. The hiring of immigrants with lower outside options may then lower the wage norm in the firm or reduce the bargaining power of (similar) native workers.

Our IV estimates point to a sizeable negative effect on native wages from hiring immigrants from less developed countries at the workplace. A one percentage point increase (corresponding to the average increase in employment of these immigrants in the period 1993-2004) is associated with a negative wage effect of around $2 \%$.

The employment of immigrants from more developed countries, on the other hand, does not reduce wages of native workers. This is consistent with these immigrants having much better outside options.

Finally, we found that the negative effect of employing LDC immigrants not only pertain to similar native workers at the workplace. Highly-educated workers are also seriously negatively affected. This indicates that the effect is not simply a firm-specific substitution effect where LDC immigrants reduce the marginal product of similar native workers and hence their bargaining position towards the firm. Instead, the result suggests that LDC immigrants reduce the general wage norm in the firm.

This in turn implies that this firm-specific wage effect of LDC immigrants may have consequences for the average wages in the economy which are not captured by studies 
focusing on substitution effects between similar native and immigrant workers (Borjas, 2003, and Ottaviano and Peri, 2005, 2006).

\section{References}

Abowd, J.M. and F. Kramarz (1999): "The Analysis of Labor Markets using Matched Employer-Employee Data", in: O. Ashenfelter and D. Card (eds.), Handbook of Labor Economics, vol. 3B, Amsterdam: Elsevier Science, 2629-2710.

Akerlof, G.A. and J.L. Yellen (1990): "The Fair Wage-Effort Hypothesis and Unemployment", Quarterly Journal of Economics 105, 255-283.

Angrist, J.D. and A.B. Krueger (2001): "Instrumental Variables and the Search for Identification: From Supply and Demand to Natural Experiments", Journal of Economic Perspectives, 15, 69-85.

Arai, M. (2003): "Wages, Profits, and Capital Intensity: Evidence from Matched WorkerFirm Data", Journal of Labor Economics, 21, 593-618.

Aydemir, A. and G. Borjas (2005): "Attenuation Bias in Estimating the Wage Impact of Immigration", Working paper, Harvard University.

Aydemir, A. and G. Borjas (2007): "A Comparative Analysis of the Labor Market Impact of International Migration: Canada, Mexico, and the United States", NBER Working Paper No. 12327.

Blanchflower, D.G., A.J. Oswald and P. Sanfey (1996): "Wages, Profits, and Rent Sharing", Quarterly Journal of Economics, 111, 227-251.

Borjas, G.J. (1999): "Immigration and Welfare Magnets", Journal of Labor Economics, $17,607-637$.

Borjas, G.J. (2001): “Does Immigration Grease the Wheels of the Labor Market?", Brookings Papers on Economic Activity, 69-119.

Borjas, G.J. (2003): "The Labor Demand Curve is Downward Sloping: Re-examining the Impact of Immigration on the Labor Market", Quarterly Journal of Economics, $118,1335-1374$.

Borjas, G.J. (2006): "Native Internal Migration and the Labor Market Impact of Immigration", Journal of Human Resources, 41, 221-258. 
Borjas, G.J., R.B. Freeman, and L.F. Katz (1997): "How Much Do Immigration and Trade Affect Labor Market Outcomes?", Brookings Papers on Economics Activity, 1, 1-90.

Bound, J., D.A. Jaeger, and R. Baker (1995): "Problems with Instrumental Variables Estimation when the Correlation Between the Instruments and the Endogenous Explanatory Variable is Weak", Journal of the American Statistical Association, 90, 443-450.

Card, D. (1990): "The Impact of the Mariel Boatlift on the Miami Labour Market", Industrial and Labour Relations Review, 43, 245-257.

Card, D. (2001): "Immigrant Inflows, Native Outflows, and the Local Labor Market Impacts of Higher Immigration", Journal of Labor Economics, 19, 22-64.

Card, D. (2005): “Is the New Immigration Really so Bad?", Economic Journal, 115, F300-F323.

Cortes, P. (2006): "The Effects of Low-Skilled Immigration on US Prices: Evidence from CPI Data”, MIT Working Paper.

Eckstein, Z. and Y. Weiss (2004): "On The Wage Growth of Immigrants: Israel, 19902000”, Journal of the European Economic Association, 2, 665-695.

Hall, A.R. and F.P.M. Peixe (2003): "A Consistent Method for the Selection of Relevant Instruments", Econometrics Reviews, 22, 269-287.

Hildretch, A.K.G. and A.J. Oswald (1997): "Rent-Sharing and Wages: Evidence from Company and Establishment Panels", Journal of Labor Economics, 15, 318-337.

Howitt, P. (2002): "Looking Inside the Labor Market: A Review Article", Journal of Economic Literature 40, 125-138.

Husted, L., H.S. Nielsen, M. Rosholm, and N. Smith (2001): "Employment and Wage Assimilation of Male First-Generation Immigrants in Denmark", International Journal of Manpower, 22, 39-68.

Lindbeck, A. and D. Snower (1986): "Wage Setting, Unemployment, and InsiderOutsider Relations”, American Economic Review, 76, 235-239.

Lipsey, R.E. (2002): "Home and Host Country Effects of FDI", NBER Working Paper No. 9293.

McDonald, I.M. and R.M. Solow (1981): "Wage Bargaining and Employment", American Economic Review, 71, 896-908. 
Munshi, K. (2003): "Networks in the Modern Economy: Mexican Migrants in the U.S. Labor Market”, Quarterly Journal of Economics, 118, 549-599.

Ottaviano, G. and G. Peri (2005): "Rethinking the Gains from Immigration: Theory and Evidence from the U.S.”, NBER Working Paper No. 11672.

Ottaviano, G. and G. Peri (2006): "Rethinking the Effects of Immigration on Wages", NBER Working Paper No. 12497.

Rodrik, D. (1997): Has Globalization Gone Too Far? Institute for International Economics, Washington DC.

Romer, D. (2001): Advanced Macroeconomics, second edition, McGraw Hill.

Staiger, D. and J.H. Stock (1997): "Instrumental Variables Regression with Weak Instruments", Econometrica, 65, 557-586.

Stock, J.H., J.H. Wright and M. Yogo (2002): "A Survey of Weak Instruments and Weak Identification in Generalised Method of Moments", Journal of Business \& Economic Statistics, 20, 518-529.

Stock, J.H. and M. Yogo (2002): "Testing for Weak Instruments in Linear IV Regression", NBER Technical Working Paper No. 284.

Summers, L. (1988): "Relative Wages, Efficiency Wages, and Keynesian Unemployment", American Economic Review 78, 383-388.

Wooldridge, J.M. (2002): Econometric Analysis of Cross Section and Panel Data, Cambridge, MA. 
Table 1: Summary Statistics: Individual Characteristics

\begin{tabular}{lcccc}
\hline \hline & Mean & Std dev & Min & Max \\
\hline Age 18-24 & 0.10135 & 0.30179 & 0 & 1 \\
Age 25-29 & 0.13256 & 0.33910 & 0 & 1 \\
Age 30-39 & 0.30560 & 0.46066 & 0 & 1 \\
Age 40-49 & 0.24749 & 0.43155 & 0 & 1 \\
Age 50-59 & 0.18742 & 0.39025 & 0 & 1 \\
Age 60-65 & 0.02557 & 0.15786 & 0 & 1 \\
Female & 0.32860 & 0.46971 & 0 & 1 \\
Married & 0.53526 & 0.49876 & 0 & 1 \\
Children 0-6 years & 0.22691 & 0.41883 & 0 & 1 \\
& & & & \\
Experience & 16.58214 & 9.55772 & 0 & 41 \\
Tenure & 4.54905 & 5.28484 & 0 & 24 \\
Tenure censored & 0.05890 & 0.23543 & 0 & 1 \\
Basic education & 0.35986 & 0.47996 & 0 & 1 \\
Vocational education & 0.47663 & 0.49945 & 0 & 1 \\
Further education & 0.16351 & 0.36983 & 0 & 1 \\
& & & & 1 \\
Copenhagen & 0.20837 & 0.40615 & 0 & 1 \\
Large city & 0.13578 & 0.34256 & 0 & 1 \\
Small city & 0.65585 & 0.47509 & 0 & \\
Number of observations & 543,089 & & & \\
\hline \hline
\end{tabular}

Note: Summary statistics are computed as simple averages across all observations in the data set. 
Table 2: Summary Statistics: Workplace Characteristics, 2004

\begin{tabular}{lccccc}
\hline \hline & Mean & Std dev & Min & Max & $\begin{array}{c}\text { Share with } \\
\text { value=0 }\end{array}$ \\
\hline log (number of employees) & 3.4452 & 0.9011 & 2.3026 & 8.3722 & \\
Female share & 0.3335 & 0.2687 & 0 & 1 & \\
Share with basic education & 0.3222 & 0.1933 & 0 & 1 & \\
Share with vocational education & 0.5120 & 0.5980 & 0 & 1 & \\
Share with further education & 0.1658 & 0.2087 & 0 & 1 & \\
Share aged 40-65 years & & & & & \\
& 0.4601 & 0.2097 & 0 & 1 & 0.7269 \\
Immigrant share (group 1) & 0.0130 & 0.0346 & 0 & 0.7500 & 0.7877 \\
Immigrant share (group 2) & 0.0099 & 0.0299 & 0 & 0.7143 & \\
Immigrant share (group 3) & 0.0176 & 0.0532 & 0 & 0.8667 & 0.7449 \\
Number of workplaces in 2004 & 16,823 & & & & \\
\hline \hline
\end{tabular}

Note: Summary statistics are computed as simple averages across all workplaces in the data set in 2004. 
Table 3: Wages and Unemployment - Native Workers vs. Immigrants

\begin{tabular}{|c|c|c|c|}
\hline \multirow{2}{*}{ Dependent variable: } & \multicolumn{2}{|c|}{ log (hourly wage) } & \multirow{2}{*}{$\begin{array}{c}\text { unemployment } \\
(3) \\
\text { (entire workforce) } \\
\text { Probit } \\
\end{array}$} \\
\hline & $\begin{array}{c}(1) \\
\text { (all workers) } \\
\text { OLS } \\
\end{array}$ & $\begin{array}{c}(2) \\
\text { (full-time workers) } \\
\text { OLS }\end{array}$ & \\
\hline Immigrant from an EU-15 country & $\begin{array}{l}-0.0056^{\star} \\
(0.0022)\end{array}$ & $\begin{array}{l}0.0023 \\
(0.0021)\end{array}$ & $\begin{array}{l}0.0129 * \star \\
(0.0011)\end{array}$ \\
\hline Immigrant from another developed country & $\begin{array}{l}-0.0461^{\star *} \\
(0.0025)\end{array}$ & $\begin{array}{l}-0.0997^{\star \star} \\
(0.0024)\end{array}$ & $\begin{array}{l}0.0503^{\star *} \\
(0.0015)\end{array}$ \\
\hline Immigrant from a less developed country (LDC) & $\begin{array}{c}-0.1421^{\star *} \\
(0.0018)\end{array}$ & $\begin{array}{c}-0.1551^{\star *} \\
(0.0017)\end{array}$ & $\begin{array}{c}0.1076^{\star \star} \\
(0.0013)\end{array}$ \\
\hline $\begin{array}{l}\text { Industry effects } \\
\text { Regional effects }\end{array}$ & $\begin{array}{l}\text { yes } \\
\text { yes }\end{array}$ & $\begin{array}{l}\text { yes } \\
\text { yes }\end{array}$ & yes \\
\hline $\begin{array}{l}\text { Observations } \\
\text { R-squared }\end{array}$ & $\begin{array}{c}2,494,848 \\
0.3751\end{array}$ & $\begin{array}{c}2,127,852 \\
0.2838\end{array}$ & $\begin{array}{c}2,831,134 \\
0.0317\end{array}$ \\
\hline
\end{tabular}

Notes: Estimations are based on a cross section from 2004, including all individuals aged 18-65 in the workforce. Column (1) presents results from a wage regression for all workers, whereas column (2) restricts attention to all full-time workers. Control variables included but not reported are: Age, age $^{\wedge} 2$, sex, education (three groups), industry (9 groups), and region (14 groups). Column (3) presents results from a Probit regression over the entire workforce where the dependent variable is a dummy for being unemployed. Control variables included but not reported are: Age, age ${ }^{\wedge}$, sex, education (three groups), and region (14 groups). The estimates reported are the marginal effects in the mean of the data. 
Table 4: LDC Immigrants at the Workplace and the Wages of Native Workers

\begin{tabular}{|c|c|c|c|c|c|c|}
\hline & \multicolumn{6}{|c|}{ Dependent variable: log(hourly wage) } \\
\hline & (1) & (2) & (3) & (4) & (5) & (6) \\
\hline & OLS & $\mathrm{FE}$ & IV (1987) & $\operatorname{IV}(1990)$ & IV(1992) & IV (all) \\
\hline $\begin{array}{l}\text { Share in workplace employment of } \\
\text { immigrants from less developed countries }\end{array}$ & $\begin{array}{l}-0.2482^{\star \star} \\
(0.0275)\end{array}$ & $\begin{array}{l}-0.1444^{\star \star} \\
(0.0197)\end{array}$ & $\begin{array}{l}-2.2259 \star \star \\
(0.4465)\end{array}$ & $\begin{array}{l}-2.0237^{\star \star} \\
(0.6596)\end{array}$ & $\begin{array}{l}-1.8871^{*} \\
(0.7409)\end{array}$ & $\begin{array}{l}-2.1515^{\star \star} \\
(0.4779)\end{array}$ \\
\hline Job-spell fixed effects & & yes & yes & yes & yes & yes \\
\hline Time effects & yes & yes & yes & yes & yes & yes \\
\hline Industry effects & yes & yes & yes & yes & yes & yes \\
\hline Regional effects & yes & yes & yes & yes & yes & yes \\
\hline Regional time trends & yes & yes & yes & yes & yes & yes \\
\hline Observations & 543,089 & 543,089 & 543,089 & 543,089 & 543,089 & 543,089 \\
\hline R-squared & 0.3940 & 0.9071 & 0.2482 & 0.2562 & 0.2611 & 0.2512 \\
\hline \multicolumn{3}{|l|}{ 1. stage F-test of instrument(s) } & 62.30 & 35.25 & 26.17 & 21.05 \\
\hline \multicolumn{7}{|c|}{ 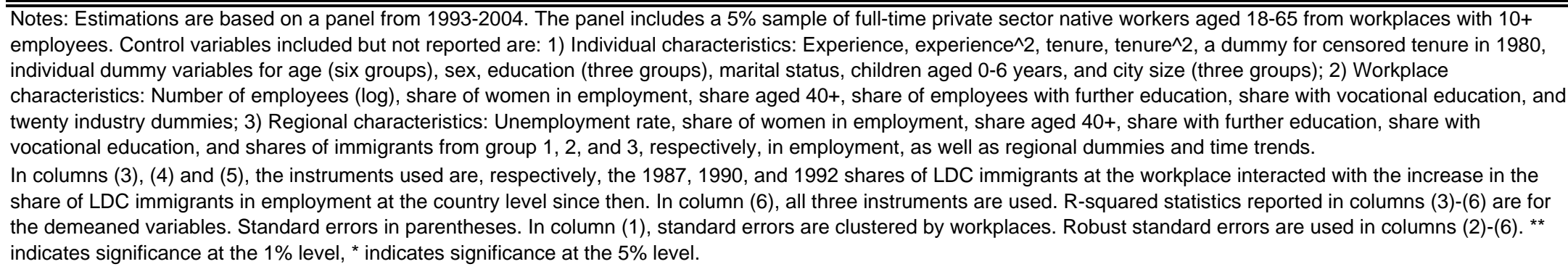 } \\
\hline
\end{tabular}


Table 5: Immigrants by Origin Countries and the Wages of Native Workers

\begin{tabular}{|c|c|c|c|c|c|}
\hline & \multicolumn{5}{|c|}{ Dependent variable: log(hourly wage) } \\
\hline & (1) & (2) & (3) & (4) & (5) \\
\hline & OLS & $\mathrm{FE}$ & IV (1987) & IV(1990) & IV(1992) \\
\hline \multicolumn{6}{|l|}{ Shares in workplace employment of: } \\
\hline Immigrants from less developed countries & $\begin{array}{c}-0.2368^{\star *} \\
(0.0275)\end{array}$ & $\begin{array}{c}-0.1432^{\star \star} \\
(0.0197)\end{array}$ & $\begin{array}{c}-2.6398^{\star} \\
(1.1488)\end{array}$ & $\begin{array}{c}-2.4472^{\star \star} \\
(0.8205)\end{array}$ & $\begin{array}{c}-2.3088^{\star *} \\
(0.5587)\end{array}$ \\
\hline Immigrants from EU-15 countries & $\begin{array}{c}0.3177^{\star \star} \\
(0.0522)\end{array}$ & $\begin{array}{c}0.0153 \\
(0.0221)\end{array}$ & $\begin{array}{c}0.5857 \\
(0.5345)\end{array}$ & $\begin{array}{l}0.5792^{*} \\
(0.2420)\end{array}$ & $\begin{array}{l}-0.0200 \\
(0.1659)\end{array}$ \\
\hline Immigrants from other developed countries & $\begin{array}{c}-0.1887^{\star *} \\
(0.0474)\end{array}$ & $\begin{array}{l}-0.0408 \\
(0.0252)\end{array}$ & $\begin{array}{c}0.6882 \\
(1.5936)\end{array}$ & $\begin{array}{c}0.6546 \\
(1.0811)\end{array}$ & $\begin{array}{c}0.4735 \\
(0.5448)\end{array}$ \\
\hline Job-spell fixed effects & & yes & yes & yes & yes \\
\hline Time effects & yes & yes & yes & yes & yes \\
\hline Industry effects & yes & yes & yes & yes & yes \\
\hline Regional effects & yes & yes & yes & yes & yes \\
\hline Regional time trends & yes & yes & yes & yes & yes \\
\hline Observations & 543,089 & 543,089 & 543,089 & 543,089 & 543,089 \\
\hline R-squared & 0.3945 & 0.9071 & 0.2250 & 0.2344 & 0.2438 \\
\hline
\end{tabular}

Notes: Estimations are based on a panel from 1993-2004. The panel includes a 5\% sample of full-time private sector native workers aged 18-65 from

workplaces with 10+ employees. Control variables included but not reported are: 1) Individual characteristics: Experience, experience^^2, tenure, tenure^2,

a dummy for censored tenure in 1980, individual dummy variables for age (six groups), sex, education (three groups), marital status, children aged 0-6

years, and city size (three groups); 2) Workplace characteristics: Number of employees (log), share of women in employment, share aged 40+, share of

employees with further education, share with vocational education, and twenty industry dummies; 3) Regional characteristics: Unemployment rate, share of

women in employment, share aged 40+, share with further education, share with vocational education, and shares of immigrants from group 1, 2, and 3,

respectively, in employment, as well as regional dummies and time trends.

In columns (3), (4) and (5), the instruments used are, respectively, the 1987, 1990, and 1992 shares of the different groups of immigrants at the workplace interacted with the increase in the share of these immigrants in employment at the country level since then. 1-stage robust F-statistics are in all cases

larger than 15. R-squared statistics reported in columns (3)-(5) are for the demeaned variables. Standard errors in parentheses. In column (1), standard

errors are clustered by workplaces. Robust standard errors are used in columns (2)-(5). ** indicates significance at the $1 \%$ level, * indicates significance at

the $5 \%$ level. 
Table 6: LDC Immigrants and Wages of Native Workers by Education Group

\begin{tabular}{|c|c|c|c|c|c|c|c|c|c|}
\hline & \multicolumn{9}{|c|}{ Dependent variable: log(hourly wage) } \\
\hline & (1) & $(2)$ & (3) & $(4)$ & (5) & (6) & (7) & $(8)$ & (9) \\
\hline & \multicolumn{3}{|c|}{ Basic education } & \multicolumn{3}{|c|}{ Vocational education } & \multicolumn{3}{|c|}{ Further education } \\
\hline & OLS & $\mathrm{FE}$ & IV (1987) & OLS & $\mathrm{FE}$ & IV (1987) & OLS & $\mathrm{FE}$ & IV (1987) \\
\hline $\begin{array}{l}\text { Share in workplace employment of } \\
\text { immigrants from less developed countries }\end{array}$ & $\begin{array}{c}-0.2247^{* *} \\
(0.0346)\end{array}$ & $\begin{array}{l}-0.1321^{\star *} \\
(0.0310)\end{array}$ & $\begin{array}{l}-3.3430 * * \\
(0.8770)\end{array}$ & $\begin{array}{l}-0.2356^{\star *} \\
(0.0323)\end{array}$ & $\begin{array}{l}-0.1087^{* *} \\
(0.0251)\end{array}$ & $\begin{array}{l}-0.1003 \\
(0.6534)\end{array}$ & $\begin{array}{c}-0.5333^{* *} \\
(0.0729)\end{array}$ & $\begin{array}{l}-0.1287^{* *} \\
(0.0594)\end{array}$ & $\begin{array}{l}-1.7051^{* *} \\
(0.8200)\end{array}$ \\
\hline Job-spell fixed effects & & yes & yes & & yes & yes & & yes & yes \\
\hline Time effects & yes & yes & yes & yes & yes & yes & yes & yes & yes \\
\hline Industry effects & yes & yes & yes & yes & yes & yes & yes & yes & yes \\
\hline Regional effects & yes & yes & yes & yes & yes & yes & yes & yes & yes \\
\hline Regional time trends & yes & yes & yes & yes & yes & yes & yes & yes & yes \\
\hline Observations & 195,434 & 195,434 & 195,434 & 258,853 & 258,853 & 258,853 & 88,802 & 88,802 & 88,802 \\
\hline R-squared & 0.2897 & 0.9307 & 0.2340 & 0.2894 & 0.8836 & 0.2482 & 0.3486 & 0.9153 & 0.2482 \\
\hline 1. stage F-test of instrument & & & 29.37 & & & 14.40 & & & 16.04 \\
\hline
\end{tabular}

Notes: Estimations are based on a panel from 1993-2004. The panel includes a 5\% sample of full-time private sector native workers aged 18-65 from workplaces with 10+ employees. In colums (1)-(3),

individuals with a basic education are used. In columns (4)-(6), individuals with a vocational education are used, and in columns (7)-(9), individuals with a further education are used. (Control variables included but not reported are: 1) Individual characteristics: Experience, experience^2, tenure, tenure^2, a dummy for censored tenure in 1980 , individual dummy variables for age (six groups), sex, marital status, children aged 0-6 years, and city size (three groups); 2) Workplace characteristics: Number of employees (log), share of women in employment, share aged 40+, share of employees with further education, share with vocational education, and twenty industry dummies; 3) Regional characteristics: Unemployment rate, share of women in employment, share aged 40+, share with further education, share with vocational education, and shares of immigrants from group 1, 2, and 3, respectively, in employment, as well as regional dummies and time trends.

In columns (3), (6) and (9), the instrument used is the 1987 share of LDC immigrants at the workplace interacted with the increase in the share of LDC immigrants in employment at the country level since then R-squared statistics reported in columns (3), (6) and (9) are for the demeaned variables. Standard errors in parentheses. In columns (1), (4) and (7) standard errors are clustered by workplaces. Robust standard errors are used in the other columns. ** indicates significance at the $1 \%$ level, * indicates significance at the $5 \%$ level. 
Figure 1: Immigrants by Origin Countries in Percent of the Total Number of Employess (18-65 years), 1993-2004

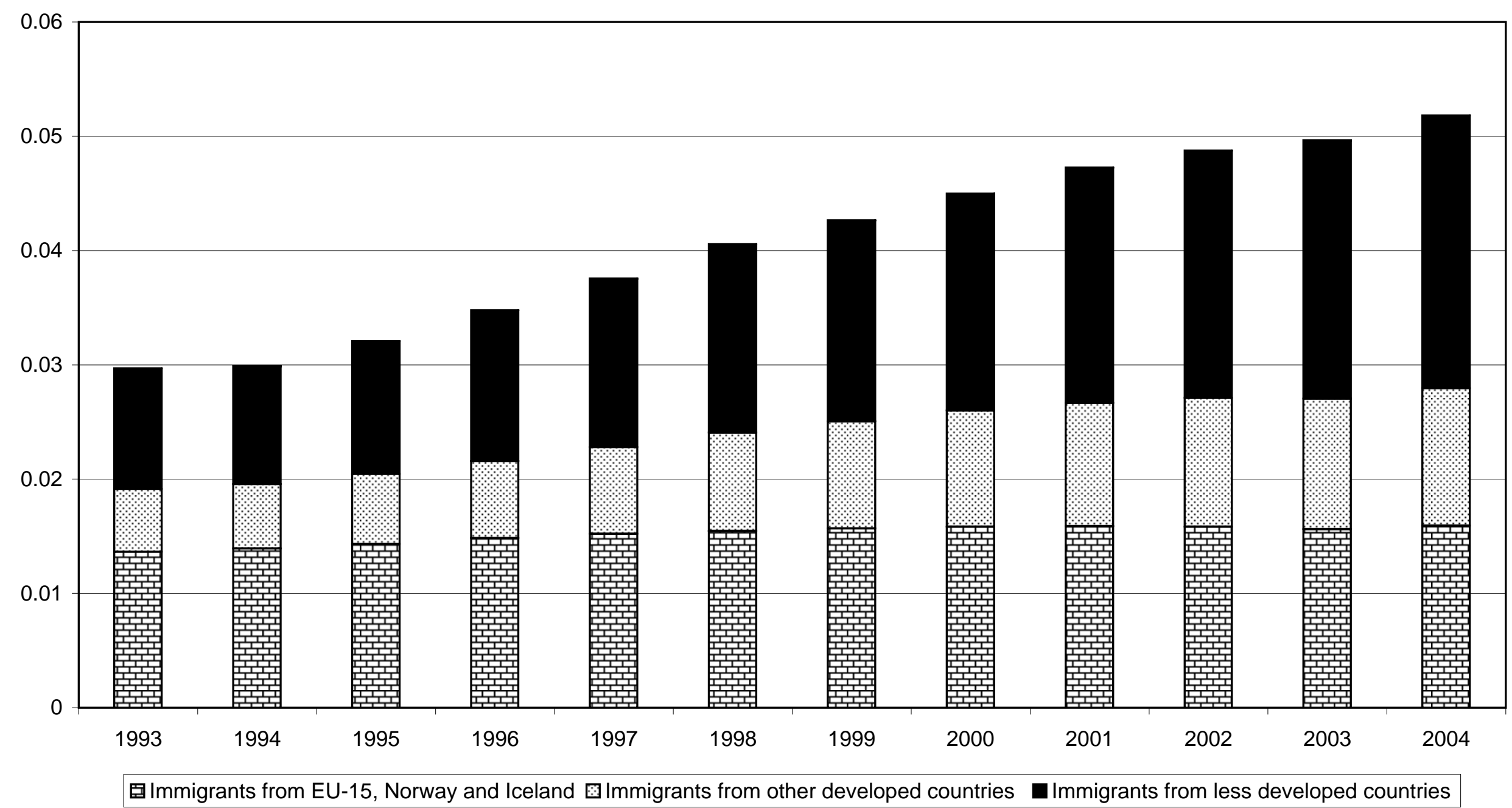

